\title{
Comunidades Epistêmicas e a Produção dos DECRETOS DE INDULTO NO BRASIL
}

\author{
Bruno Amaral Machado* \\ Reinaldo Rossano Alves**
}

\begin{abstract}
1 Introdução. 2 Comunidades epistêmicas e política criminal. 2.1 As comunidades epistêmicas como categoria de análise. 2.2 A influência das comunidades epistêmicas na produção legislativa. 3 A produção dos decretos de indultos no Brasil. 3.1 Organizações que participam na produção dos indultos. 3.2 O CNPCP como comunidade epistêmica: origem, organização e funções. 4 A produção do decreto de indulto de 2014-2015: aspectos político-criminais e atores envolvidos. $5 \mathrm{O}$ decreto de indulto de 2016 - restrição às hipóteses de incidência e a renúncia de membros do CNPCP. 6 Conclusão. Referências.
\end{abstract}

\section{RESUMO}

O artigo analisa o papel do Conselho Nacional de Política Criminal e Penitenciária (CNP$\mathrm{CP}$ ) na edição dos decretos de indulto no Brasil, retomando o conceito de comunidades epistêmicas. No Brasil, o órgão encarregado de elaborar a minuta do decreto de indulto é o Conselho Nacional de Política Criminal e Penitenciária (CNPCP), que a remete, via Ministro da Justiça, à Presidência da República para apreciação e publicação posterior do decreto. Assim, a pesquisa articulou-se a partir de dois problemas: identificar se o CNPCP pode ser descrito como comunidade epistêmica que orienta a produção de indultos no Brasil e, caso positivo, se nele há uma visão teórica hegemônica/compartilhada. Para a resposta aos problemas, utilizou-se da técnica de análise de conteúdo, complementada com entrevistas em profundidade de membros e ex-membros do CNPCP. Concluiu-se que o CNPCP é uma comunidade epistêmica que orienta a produção de indulto no Brasil e que, nos últimos anos, nota-se que seus membros compartilham ideário predominantemente minimalista, variável relevante para compreender o aumento das hipóteses de incidência e flexibilização das regras da concessão do benefício. De outro ângulo, a produção dos decretos de indultos insere-se no âmbito político, de competência da Presidência da República, o que se depreende quando, em contextos sociais e políticos específicos, o Presidente da República, ao definir o conteúdo dos decretos de indulto, editou decretos distintos

* Professor da Graduação e dos Programas de Mestrado e Doutorado em Direito e Políticas Públicas do Centro Universitário de Brasília- UNICEUB. Doutor em Direito na especialidade jurídico-penal (Universidade de Barcelona). Pós Doutorado em Sociologia (Universidade de Brasília/John Jay-NY). Líder do Grupo de Pesquisa Política Criminal. Promotor de Justiça em Brasília. E-mail: < brunoamachado@ hotmail.com >.

** Mestre em Direito e Políticas Públicas pelo Uniceub. Defensor Público no Distrito Federal. Coordenador do Núcleo de Execução Penal da Defensoria Pública do Distrito Federal. Professor universitário. E-mail: $<$ reinaldorossano@yahoo.com.br>. 
daqueles propostos pelo CNPCP, a despeito do conhecimento técnico da comunidade integrante desse órgão.

Palavras-chave: Indulto. Comunidade epistêmica. CNPCP. Produção legislativa. Brasil.

\section{INTRODUÇÃO}

A expansão do Direito Penal tornou-se objeto de interesse das ciências penais nos últimos anos. Entre as distintas visões do fenômeno, argumenta-se que haveria verdadeiro consenso de setores da sociedade sobre a necessidade da intervenção penal como estratégia para a defesa de interesses sociais (SÁNCHEZ, 2001; MACHADO, 2012). Parte da literatura associa o fenômeno à hegemonia da punitividade, categoria criminológica que remete à cultura do controle penal, que cronologicamente coincide com o crescimento das taxas de encarceramento (GARLAND, 2001, 2004; PRATT, 2002). Recentemente, a referida categoria teórica foi submetida à crítica. Argumenta-se que se trata de conceito impreciso, não raramente apresentado de forma irrefletida, desfocada da complexidade das variadas formas assumidas pelo controle penal. $O$ crescimento geométrico das penas privativas de liberdade coincide temporalmente com as mais variadas iniciativas no sentido da diversificação das sanções impostas, tais como as medidas alternativas e os substitutivos às penas privativas de liberdade (MATTHEWS, 2015).

O campo de estudo político-criminal, no Brasil, também tem despertado o interesse de pesquisadores. $\mathrm{O}$ mapeamento da produção legislativa penal evidencia os diferentes interesses envolvidos na produção do Direito Penal e do Processual Penal. As contradições e as ambiguidades das novas estratégias punitivas também foram objeto de estudos recentes no Brasil (FRADE, 2007; GAZOTO, 2010; AZEVEDO, CIFALI, 2016). A inexistência de critérios racionais que orientem a política criminal no Brasil preocupa especialistas na área penal e na área de segurança pública. Inspirado pela necessidade de estabelecer mecanismos de accountability na produção legislativa penal, Carvalho sugeriu Lei de Responsabilidade Criminal como diretriz que poderia estabelecer parâmetros dos parlamentares e exigências de responsabilidade pela produção de leis penais, em grande parte desconectadas da realidade, movidas por objetivos irrealizáveis e que agravariam a situação carcerária no Brasil (CARVALHO, 2008). Hoje tramita, no Congresso Nacional, o PLC n. 4373/2016, que pretende criar a "Lei de Responsabilidade Político-Criminal" (BRASIL, 2016a). O projeto, movido por ideários minimalistas, ou estratégias gerenciais, indica que "a aprovação de leis penais sem prévios estudos técnicos e empíricos provoca impacto na vida dos brasileiros".

Em recente relatório que apresentamos à Rede Europeia e Latino-americana contra a Tortura (RELAPT), foi possível apresentar descrição parcial do encarceramento brasileiro nos últimos anos. O Brasil ocupa o terceiro lugar ${ }^{1}$ entre os países com o maior número de encarcerado e um elevado percentual de presos provisórios. O relatório retratou também as péssimas condições da maioria dos estabelecimentos prisionais (ZACKSESKI, MACHADO, 
AZEVEDO, 2016). As dificuldades gerenciais originadas do desequilíbrio entre o número de vagas e as taxas de encarceramento ocupam a atenção de críticos e dos meios de comunicação. A insatisfação quanto às políticas de segurança pública, frequentemente associadas a fatores complexos, bem como as demandas por critérios supostamente mais racionais de controle penal têm atraído a atenção para os contextos em que são idealizadas as propostas legislativas e os condicionantes que viabilizam a aprovação das novas legislações.

Em obra seminal, Becker descreve a atuação do que denomina de empresários morais, lideranças ou grupos que movimentam novas demandas penais. A influência de especialistas perante o Legislativo ou nos nichos de articulação na produção normativa sugere a constituição de grupos profissionais que, muitas vezes, orientam os processos legislativos. Não raramente, contudo, as propostas de criminalização estão associadas a cruzadas morais ou religiosas (BECKER, 2008). O tema remete a um campo de pesquisa pouco explorado no Brasil. O papel das assim descritas comunidades epistêmicas (HAAS, 1992; ENGUÉLÉGUÉLÉ, 1998), na produção legislativa, constitui-se em objeto de interesse atual que merece aprofundamento. Certamente, há uma diversidade de visões de penalistas, cientistas sociais e burocratas que ocupam distintas posições nas organizações estatais sobre a intervenção penal. Além disso, é desejável que as políticas públicas sejam submetidas a instrumentos e a parâmetros para avaliação de resultados, o que reforça o papel que a expertise pode desempenhar tanto no momento da idealização dos projetos quanto na avaliação das formas de implantação.

O presente artigo utiliza-se do conceito de comunidades epistêmicas (HAAS, 1992; ENGUÉLÉGUÉLÉ, 1998) e tem por objetivo analisar o papel do Conselho Nacional de Política Criminal e Penitenciária (CNPCP) na produção dos decretos de indultos no Brasil. As comunidades epistêmicas são redes de profissionais e experts com conhecimento relevante e que partilham um conjunto de crenças normativas, modelos causais e propostas políticas concretas. A nossa análise concentra-se especialmente no papel desempenhado pelo CNPCP, órgão responsável por elaborar a minuta de decreto de indulto que é submetida ao crivo da Presidência da República, para o exercício de sua atribuição constitucional. Este artigo orienta-se pelos seguintes questionamentos: o CNPCP pode ser descrito como comunidade epistêmica que orienta a produção de indultos no Brasil? Se assim ocorre, há uma visão teórica hegemônica/compartilhada no interior do CNPCP?

Para a realização da pesquisa, utilizamos a técnica da análise de conteúdo de legislações e minutas de decreto, complementada com entrevistas em profundidade com membros e ex-membros do CNPCP. Entre agosto de 2014 e julho de 2015, foram entrevistados Beatriz Vargas Gonçalves de Rezende, relatora do Decreto de indulto de 2014, Rodrigo Duque Estrada Roig, membro do CNCPC entre 2008 e 2013 e participante da comissão responsável pela elaboração das minutas de decreto de indulto nos anos de 2009, 2010, 2011 e 2012, e Maurício Kuehne, que integrou o CNPCP de março de 2000 até maio de 2008 e participou da comissão de indulto dos decretos de 2000 a 2005, na qualidade de relator das propostas. 
Em que pese já houvéssemos concluído a pesquisa, fazemos, ao final, breve referência ao último Decreto de indulto, de 2016, eis que evidenciou divergência entre a opção política do Ministério de Justiça, sob a liderança do então ministro Alexandre de Moraes, e encampada pela Presidência da República, que restringiu as hipóteses de incidência do indulto, verificadas na série histórica selecionada como objeto de nossa análise, e o ideário compartilhado por parte dos membros do CNPCP, que renunciaram aos seus cargos.

\section{COMUNIDADES EPISTÊMICAS E POLÍTICA CRIMINAL}

\subsection{AS COMUNIDADES EPISTÊMICAS COMO CATEGORIA DE ANÁLISE}

Peter Haas conceitua as comunidades epistêmicas como redes de profissionais com conhecimento relevante e que partilham um conjunto de crenças normativas, modelos causais e ostentam uma proposta política, ou seja, as comunidades epistêmicas são um grupo de profissionais que têm algo relevante a dizer sobre uma área específica. Destinam-se a reduzir a incerteza num contexto internacional marcado pela diminuição das capacidades de antecipação e de decisão dos atores responsáveis pela gestão internacional (HAAS, 1992, p. 3).

Em análise sobre a produção legislativa na França, Stéphane Enguéléguélé retoma o conceito de comunidades epistêmicas para pensar o processo de produção das políticas criminais. Com efeito, se a criação legislativa é um dos prismas pelo qual é analisada a produção normativa penal, revela-se útil focalizar os sistemas de interesse, interações e esquemas interpretativos que movem os processos de produção da norma (ENGUÉLÉGUÉLÉ, 1998, p. 3). Nesse eixo, mostra-se relevante compreender a influência estruturante exercida pelas ideias e conhecimentos sobre a definição da estratégia criminal formal. Em um segundo momento, é pertinente avaliar o potencial de ação de que dispõem determinados atores do campo penal, que lhes permitem, nas diversas configurações, imprimir à política criminal um estilo que se encaixa nas suas preferências teóricas.

Mas o campo penal não se restringe mais a um pequeno círculo de atores, teóricos e práticos, pois é estruturado pelo confronto das comunidades epistêmicas contrárias, cujos membros concorrem para influir na definição dos princípios que nortearão a escolha dos políticos em matéria penal (BOURDIEU, 1998, p. 3-19). Enguéléguélé (1998, p. 9) descreve que, na França, há duas grandes comunidades epistêmicas, cujas teses estão fortemente enraizadas no debate penal. A primeira, de tendência humanista, contesta as soluções repressivas, assim como o recurso sistemático à prisão. Seus membros são próximos à Escola Nova Defesa Social ou pertencem à corrente mais contemporânea de defesa dos direitos do homem e propõem diversificar as formas de intervenção penal, atentos à reabilitação. A segunda comunidade epistêmica preconiza um aumento da repressão e o recurso sistemático à prisão, pois as escolhas penais mais eficazes são aquelas fundadas na dissuasão e na exemplaridade.

Compreender as comunidades epistêmicas que participam dos processos de produção normativa supõe descrever as diferentes realidades nacionais. No Brasil, os movimentos político- 
-criminais podem ser classificados por compartilhar ideários comuns sobre a intervenção penal. Embora devam ser consideradas as variações e especificidades no interior de cada movimento, em um esforço de síntese e com os riscos de toda simplificação, sugere-se a seguinte tipologia: Abolicionismos, Minimalismos e Eficientismos (ANDRADE, 2012, p. 253-273).

O primeiro deslegitima o sistema penal por identificá-lo como inadequado para a solução de conflitos e por gerar estigmas para aqueles indivíduos etiquetados como criminosos. Esse movimento questiona o papel historicamente assumido pelo sistema de justiça criminal, que deveria ser substituído por instâncias comprometidas com a solução de conflitos intersubjetivos. Os Minimalismos apostam em soluções alternativas e propõem que o Direito Penal deve se restringir às ofensas mais graves. Inspirado por filosofia humanista, orienta-se pela descriminalização de condutas que deveriam ser objeto de regulação por outros ramos do direito. Na vertente proposta por Ferrajoli, o ideário minimalista vincula-se a um amplo programa de garantias processuais, com diretrizes que balizam a intervenção penal, conforme dispositivos constitucionais. O Direito Penal apresenta-se como "lei do mais fraco", restrita às hipóteses que justificam o uso do Direito Penal (axiomas penais) e cuja imposição supõe a observância de garantias processuais no Estado constitucional (axiomas processuais) (FERRAJOLI, 2001). O exercício de síntese supõe algumas explicações. A diversificação das semânticas criminológicas críticas à intervenção penal relaciona-se a trajetórias específicas do campo criminológico e da filosofia do Direito Penal. As propostas abolicionistas constituíram-se, de fato, no principal marco teórico que pretendeu deslegitimar o sistema penal e foram contrapostas não apenas por posições conservadoras. Nesse contexto, emergem as propostas teóricas ajustadas aos movimentos conhecidos como realismos criminológicos (de direita e de esquerda) (MACHADO, 2012; ANITUA, 2008). Para mencionar alguns dos mais difundidos representantes teóricos no cenário brasileiro, vale mencionar que o garantismo minimalista ferrajoliano edificou parte de sua proposta teórica na contraposição às linhagens abolicionistas, naquilo que o filósofo italiano identificou como risco da substituição do Direito Penal por formas difusas de controle, informais e menos visíveis. Por isso, menos controláveis, o que acabaria submetendo os mais fracos ao "arbítrio dos mais fortes" (FERRAJOLI, 2001). Os minimalismos derivados das tradições criminológicas críticas, rearticulados pelo Direito Penal dos direitos humanos, não se apresentam totalmente incompatíveis com as visões abolicionistas, as quais são deslocadas para um futuro cada vez mais incerto, como o objetivo a ser perseguido em um modelo de sociabilidade ideal (MACHADO, 2012; MACHADO; TAQUARY, 2016).

Os Eficientismos relacionam-se às demandas pela intervenção penal para a solução de conflitos sociais. Esse movimento, simplificadamente, deve ser compreendido no contexto de expansão do Direito Penal. As possíveis causas da referida expansão, em especial na última década, seriam dois grupos de fatores: fatores objetivos - como os novos interesses definidos pela doutrina como bens coletivos e difusos, o aparecimento de riscos e a institucionalização da insegurança, diluída em uma sociedade cada vez mais complexa - e fatores subjetivos, 
constituídos especialmente pela sensação de insegurança potencializada pela mídia e pelas próprias instituições públicas (SÁNCHEZ, 2001). Nesse contexto social, proliferam demandas pela ampliação da proteção penal, flexibilizando o Direito Penal clássico. Multiplicam-se as demandas de criminalização em matéria ambiental, econômica e corrupção política. Além disso, há um descrédito de outras instâncias de proteção, em especial, a ética social, o Direito Civil e o Administrativo. Nessa interpretação, o fenômeno não se deve unicamente à instância estatal, como solução fácil aos problemas sociais, deslocando-se ao plano simbólico, o que deveria ser resolvido no plano instrumental. Suas causas relacionam-se à nova configuração do modelo social nas duas últimas décadas e às mudanças do papel do Direito Penal para diferentes setores sociais (SÁNCHEZ, 2001). Ao contrário do movimento law and order de décadas anteriores, marcado pela ênfase sobre a criminalidade patrimonial, o qual enfrentou forte resistência de movimentos de defesa dos direitos humanos e amplo debate sobre a função do Direito Penal, a expansão do Direito Penal, na atualidade, aparentemente é representada de forma positiva (SÁNCHEZ, 2001, p. 22-24). ${ }^{2}$ A expansão do Direito Penal foi objeto de análise no Brasil, naquilo que pode ser descrito como manifestações dos Eficientismos. Critica-se que as demandas por mais direito penal estão associadas à sensação de medo e insegurança, difundidas pelos meios de comunicação e pelas formas de comunicação política, no que se apresenta como populismo penal (FRADE, 2007; GAZOTO, 2010).

Parte da literatura recupera essas abordagens e descreve variações nos diferentes contextos nacionais (ANITUA, 2008). Trata-se de um campo dinâmico e configurado segundo peculiaridades locais. Andrade sugere que, no Brasil, em contraposição aos ideários eficientistas, os Minimalismos apresentam-se sob formas diferenciadas: há corrente minimalista que se apresenta como via para abolicionismo futuro, vertente que pode ser descrita como "Minimalista em si mesma" e "Minimalismo reformista" (ANDRADE, 2012, p. 257-258).

A breve e simplificada apresentação dos paradigmas político-criminais supõe um esclarecimento. A diversidade de posições sugere que os modelos devem ser observados como tipos ideais (weberianos). A conformação dos ideários supõe hibridismos que tornam complexa e pouco precisa a tarefa de enquadramento das posições compartilhadas pelos teóricos. Integrantes de algumas das vertentes minimalistas podem assumir, contingencialmente, e conforme a arena de disputa, posições aparentemente antagônicas. Alguns exemplos são elucidativos. A demanda pela intervenção penal como estratégia instrumental ou simbólica para a proteção de direitos de minorias ou grupos sociais específicos tornou-se uma das bandeiras de setores que reivindicam a criminalização dos crimes contra a humanidade (herança da ditadura), das violências de gênero (algumas vertentes do movimento feminista) ou dos atos que expõem a perigo ou ocasionam danos concretos ao meio ambiente (parte do movimento ambientalista). Intérpretes desse movimento descrevem as aporias da entrada do público e do léxico dos direitos humanos na racionalidade penal moderna. Critica-se a proliferação de demandas por penas aflitivas como estratégia de proteção de direitos de distintos grupos sociais (PIRES, 2003), o que não impede que alguns desses grupos invistam em posições minimalistas (ou abolicionistas) 
em relação a determinadas atividades, como o tráfico de drogas. Ou em relação à diversificação das sanções penais, com propostas de medidas alternativas às penas privativas de liberdade. $\mathrm{Da}$ mesma forma, não parece adequado enfocar o paradigma Eficientista como se tratasse de um bloco monolítico. As propostas de expansão da criminalização e do endurecimento das penas ou das regras para a progressão do regime na execução penal podem fundar-se em ideologias de variado matiz. As teorias das penas propiciam amplo arsenal de justificações que movem as crenças e valores sobre o papel do Direito Penal. Não menos relevantes são as contingências gerenciais que constrangem as políticas criminais e penitenciárias, o que pode levar à necessidade de ajustes supostamente realistas aos contextos analisados (ANITUA, 2008; MACHADO, 2012; MACHADO; SLONIAK, 2015).

A diversidade de visões e modelos sobre a intervenção penal constitui um dado relevante quando o foco se direciona às organizações e às agências estatais (MACHADO, 2014). A composição, perfil e atribuições conferidas ao CNPCP permitem descrevê-lo como órgão eminentemente técnico. Como veremos em seguida, sua inserção como órgão consultor da política criminal e penitenciária o coloca em posição privilegiada na proposição normativa penal. A composição do CNPCP não é indiferente à diversidade dos movimentos político-criminais. A existência de diferentes visões e ideários sobre a intervenção penal repercute diretamente na produção do órgão. De fato, é em torno de esquemas teóricos construídos pelas comunidades epistêmicas penais que se formam alianças transversais, nos momentos particulares, para convencer a política e mudar as orientações da política criminal (ENGUÉLÉGUÉLÉ, 1998, p. 14). Nesse sentido, nossa hipótese é que o paradigma penal que venha a prevalecer no âmbito do CNPCP influenciará diretamente as hipóteses de incidência de indulto, norteando as minutas que são encaminhadas para apreciação da Presidência da República.

\subsection{A INFLUÊNCIA DAS COMUNIDADES EPISTÊMICAS NA PRODUÇÃO LEGIS- LATIVA}

O indulto, por força da Constituição da República de 1988, insere-se na competência privativa do Presidente da República, auxiliado pelo Ministério da Justiça, especificamente pelo CNPCP, na elaboração dos decretos concessivos da benesse. Importa, ainda, destacar que a produção legislativa constitui um processo programador decisório da política, inserta em um complexo contexto, atuando no espaço tridimensional do sistema político, que engloba o estado, o público e a Administração Pública. Difere-se, por exemplo, da decisão judicial, que é programada, já que se opera em ambiente com complexidade já reduzida pela positivação do Direito. E o legislador tem, no eleitorado, o seu mecanismo de controle por excelência e suas decisões são operadas a partir dos critérios governo/oposição (LUHMANN, 2005; MACHADO, 2012, p. 100).

Além disso, para o sistema político, os discursos sobre o crime e a pena só fazem sentido a partir dos códigos e programas da política. Em outras palavras, para o sistema político, a 
produção legislativa é política em ação: simbólica ou instrumental. A política em ação pode assumir a forma de legislação, criando novos tipos penais, descriminalizando ou endurecendo as penas (MACHADO, 2012, p. 103), ou, em particular, na edição de decretos de indulto. Dessa forma, pode-se dizer que os decretos de indulto são editados de acordo com os códigos do sistema político. Assim, é plenamente possível, esperado, que o Presidente da República, em um contexto específico, edite um decreto de indulto diverso da linha sugerida pelo CNPCP, a despeito do conhecimento técnico da comunidade integrante desse órgão.

Com efeito, as diferentes racionalidades que estão presentes na formulação e execução da política social geram conflitos. Existem âmbitos que são próprios dos políticos e outros que correspondem aos técnicos. Em algumas situações, falta o substrato técnico e as decisões são tomadas sem base suficiente para que possam alcançar resultados eficazes e efetivos. Em outras, tende-se a supervalorizar o papel dos políticos. Entretanto sem negar a importância do âmbito da decisão política, é necessário enfatizar a conveniência ou a necessidade de que ela tenha sólida base técnica. (COHEN; FRANCO, 1993, p. 67-68).

Ademais, a política de edição do indulto pode assumir, ainda, um aspecto gerencial, seguindo lógica atuarial. $\mathrm{O}$ gerencialismo não busca punir ou reabilitar, mas gerenciar. Ele envolve mudança significativa não apenas na linguagem da política penal, mas também em seus objetivos e práticas, por meio da qual a ação governamental, em vez de enfatizar as metas da justiça pública, enfatiza as metas do gerencialismo do risco. A expressão lógica atuarial remete à adoção sistemática do cálculo atuarial como critério de racionalidade de uma ação, definindo-se como tal a ponderação matemática de dados para determinar a probabilidade de eventos futuros concretos (DIETER, 2012, p. 5).

Partindo dessa lógica atuarial, é possível que o indulto proporcione ao encarcerado a expectativa de recuperação mais rápida da liberdade, contribuindo para aquelas ações que "transpareçam boa disciplina" interna, ao exigir bom comportamento carcerário do detento para a sua concessão. Com efeito, as instituições totais, avalia Erving Goffman, são âmbitos nos quais a interação humana encontra-se condicionada pelas formas da internação, assim como pelo poder exercido pelas autoridades, encarregando-se da programação da vida dos internos de acordo com normas concebidas para a consecução dos objetivos da instituição. Delineia-se a forma pela qual o homem se apresenta em uma situação, como o faz frente a si mesmo e frente aos outros e como tenta manipular a impressão que os outros podem formar a seu respeito. $\mathrm{O}$ comportamento humano aproxima-se ao do ator (ação dramatúrgica), que procura fazer que a sua forma de ser e agir pareça verdadeira, pois tudo tem relevância e consequências na conformação da identidade (GOFFMAN, 1970). Poder-se-ia cogitar de uma função pedagógica, minimizando a tensão dos presídios. Apresentado nesses termos, o instituto do indulto pode assumir, idealmente, a forma político-criminal de mecanismo para a efetivação do direito substantivo em face do processo e da sentença; da equidade em face da justiça; ou, ainda, dos altos fins da política geral do Estado, em face dos fins especificamente técnico-jurídicos da sua política criminal (RADBRUCH, 1997, p. 336). 


\section{A PRODUÇÃO DOS DECRETOS DE INDULTOS NO BRASIL}

\subsection{ORGANIZAÇÕES QUE PARTICIPAM NA PRODUÇÃO DOS INDULTOS}

O Conselho Nacional de Política Criminal e Penitenciária (CNPCP), integrante do Ministério da Justiça, exerce papel fundamental na política pública de concessão de indultos no Brasil. Isso porque é o órgão responsável por elaborar a minuta de decreto de indulto que é encaminhada pelo Ministro da Justiça à Presidência da República.

O CNPCP é integrado por 13 (treze) membros designados por meio de ato do Ministro da Justiça, entre professores e profissionais da área do Direito Penal, Processual Penal, Penitenciário e ciências correlatas, bem como por representantes da comunidade e dos Ministérios da área social, os quais possuem mandato de 2 (dois) anos, renovado 1/3 (um terço) em cada ano. ${ }^{2}$

Entre os membros do CNPCP, são indicados 4 (quatro) representantes para compor a comissão responsável para apresentar Proposta de Decreto Presidencial de Indulto Natalino. Após a designação da comissão de indulto pelo Presidente do CNPCP, são colhidas opiniões dos demais integrantes do Conselho acerca de eventuais modificações do próximo decreto, assim como de diversos órgãos integrantes do sistema penitenciário, como Magistratura, Ministério Público, Defensoria Pública, Pastoral Carcerária, Conselhos Penitenciários, Secretarias Estaduais de Segurança Pública ou outras organizações encarregadas por gerir a questão penitenciária nos estados, sendo possibilitado, ainda, a qualquer cidadão a apresentação de sugestões, já que são realizadas audiências públicas sobre o novo decreto natalino. Ademais, vários atores da execução penal e representantes da sociedade civil podem encaminhar diversas sugestões de modificação do decreto.

A partir da análise documental, identificamos a tendência de algumas organizações em limitar as hipóteses de incidência do indulto, como o Ministério Público e as polícias, civil e federal. Outras organizações, como a Defensoria Pública, e de defesa dos encarcerados, como a Pastoral Carcerária, buscam ampliar a incidência do indulto (ALVES, 2016, p. 217). Nossa observação também deve ser contextualizada a fim de evitar posições maniqueístas, pois, ao analisarmos o perfil acadêmico/teórico dos membros do Ministério Público brasileiro que integraram o CNPCP, nos últimos anos, notamos posições distantes do que pode ser descrito como Eficientismo.

O relator da comissão é responsável por compilar as propostas e submetê-las à comissão. Após os respectivos debates, ainda no âmbito interno da Comissão, é elaborada pelo relator uma pré-minuta do decreto, a qual, posteriormente, é submetida a todos os integrantes do CNPCP. Nesse momento, todos os integrantes do CNPCP debaterão as propostas e decidirão, por maioria, ${ }^{3}$ aquelas que devam ser incluídas no próximo decreto. É importante destacar que todas as reuniões do CNPCP são públicas, não se tendo notícia de nenhuma reunião secreta. 
Posteriormente, uma minuta de decreto, com a exposição de motivos, ${ }^{4}$ é enviada pelo CNPCP à Secretaria de Assuntos Legislativos e à Assessoria do Ministro da Justiça, que decidirá sobre a proposta encaminhada e, então, submetê-la-á à Presidência da República, que, por fim, editará o decreto de indulto. Por óbvio, nem a proposta apresentada pelo $\mathrm{CN}$ CPC vincula o Ministro da Justiça, nem a proposta deste vincula o Presidente da República.

\subsection{O CNPCP COMO COMUNIDADE EPISTÊMICA: ORIGEM, ORGANIZAÇÃO E FUNÇÕES}

Conforme se viu, o CNPCP é integrado por 13 (treze) membros designados por meio de ato do Ministro da Justiça. ${ }^{5}$ Trata-se do primeiro dos órgãos da execução penal citados no artigo 61 da Lei de Execuções Penais (Lei no 7210/84), embora tenha sido instalado em junho de 1980, ${ }^{6}$ tendo suas atribuições definidas no artigo 64 da mesma norma. ${ }^{7}$

Quando de sua instalação, em junho de $1980,{ }^{8}$ o órgão era denominado Conselho Nacional de Política Penitenciária. A reunião de instalação ocorreu no dia 26 de junho de 1980. ${ }^{9}$ A ata indica que o órgão foi criado por sugestão da Resolução no 70 de 1976 da CPI do Sistema Carcerário. ${ }^{10}$ Posteriormente, com a Lei $n^{0} 7.210 / 1984$ (LEP), que o incumbiu de propor diretrizes para a política criminal e penitenciária, passou a chamar-se Conselho Nacional de Política Criminal e Penitenciária.

Em 2000, Luiz Flávio Borges D`Urso, membro do CNPCP à época, escreveu "o Brasil necessita de uma política criminal e penitenciária, de forma a definir, orientar e focar os objetivos que o governo, permanentemente, deverá procurar alcançar, pois não se trata de uma gestão governamental, mas de uma diretriz nítida a guiar os futuros dirigentes nacionais." (D`URSO, 2000, p. 77). Ponderou, ainda, sobre a dificuldade de separar a política criminal e a política penitenciária, pois ambas devem estar em sintonia, pois "de nada adianta todo esforço na política legislativa e até jurisprudencial, quando o desaguar desse esforço ocorre no vazio da iniquidade de nosso sistema penitenciário, colocando tudo a perder." (D`URSO, 2000, p. 88). É importante mencionar que D’Urso havia sido designado relator, pelo Presidente do CNPCP, de apresentar proposta para uma nova política criminal brasileira, porém, na mesma oportunidade, outro membro do Conselho, Nizaldo Carneiro Leão, foi incumbido de apresentar proposta para uma política penitenciária para o Brasil (D`URSO, 2000, p. 77-78).

As propostas apresentadas por Luiz Flávio Borges D`Urso e Nizaldo Carneiro Leão culminaram na Resolução no 5 de 19 de julho de 1999, do CNPCP, que, à época, estabeleceu as diretrizes básicas que devem nortear a política criminal e penitenciária brasileira. As diretrizes para a política criminal (art. $1^{\circ}$ ao 14 ) abordam questões, como a promoção humana e garantia de direitos daqueles que cumprem pena; a melhoria do sistema de justiça criminal; a adoção de medidas preventivas (policiamento ostensivo) e repressiva (cumprimento efetivo de mandatos de prisão); o estímulo à adoção das penas alternativas; a mobilização e o envolvimento da sociedade nas questões pertinentes à política criminal e penitenciária; em 
ações de prevenção; etc. Em relação à política penitenciária (art. 15 ao 29), a Resolução 5/1999 preconiza que devem ser priorizadas ações, como a melhoria das condições das unidades prisionais, permitindo a proximidade do condenado com a sua família; a garantia do respeito aos direitos dos presos; a humanização da pena; o apoio a convênios com entidades sociais para garantir a assistência adequada; a realização de campanhas comunitárias para esclarecimentos e prevenção; o estímulo à instalação de Conselhos da Comunidade e Penitenciários no País; a promoção com relação à qualificação de pessoal penitenciário, criando a Escola Penitenciária Nacional e estimulando a criação de escolas estaduais; a promoção de programas de prevenção e tratamento de DST/AIDS e dependência química; a promoção da assistência jurídica aos presos; entre outras (FIGUEIREDO, 2007, p. 24).

No ano de 2003, a política criminal e penitenciária passou a ser regulada pela Resolução n ${ }^{0}$ 16, de 17 de dezembro de 2003, do CNPCP, que dispôs sobre as diretrizes básicas de política criminal quanto à prevenção do delito, administração da justiça criminal e execução das penas e das medidas de segurança. Essa resolução também se orientou por visão afinada ao ideário compartilhado pelos Minimalismos: intervenção mínima do Direito Penal, com valorização do emprego das penas alternativas, como forma de evitar a privação de liberdade; a prisão deve ser imposta excepcionalmente, qual ultima ratio e manutenção do regime progressivo de cumprimento de penas, entre outras medidas. ${ }^{11}$

Em 26 de abril de 2011, o CNPCP editou o Plano Nacional de Política Criminal e Penitenciária (BRASIL, 2011), por meio do qual se apontaram duas direções que poderiam ser seguidas, optando-se pela segunda, que, entre outros objetivos, visa à redução de taxas de encarceramento e ao fortalecimento do controle social sobre o sistema penal e ter política, método e gestão específica para o sistema prisional. O conteúdo do Plano sugere tendência também ajustada aos ideários minimalistas, particularmente em relação às penas privativas de liberdade (MARQUES, 2013, p 41).

Finalmente, em outubro de 2015, foi lançado o atual Plano Nacional de Política Criminal e Penitenciária (BRASIL, 2015a). O documento divide-se em duas partes. A primeira, apresenta as medidas relacionadas à porta de entrada do sistema penal, com o objetivo de revelar o que tem levado ao quadro atual da política criminal, em que ocorre o crescimento contínuo da população carcerária, sem impacto na melhoria dos indicadores de segurança pública. A segunda parte do plano volta-se para fixar diretrizes para o funcionamento do sistema prisional, do cumprimento de medida de segurança, do monitoramento eletrônico e das alternativas penais. $\mathrm{O}$ atual Plano sugere, da mesma forma dos planos anteriores, aproximação às propostas afins à restrição da intervenção penal, concepção compartilhada pelos Minimalismos.

Também em decorrência de suas atribuições legais, ${ }^{12}$ o CNPCP é o órgão encarregado de elaborar a minuta de indulto, a qual, após análise do Ministro da Justiça, é enviada à Presidência da República, a fim de que o Presidente exerça sua competência constitucional, prevista no artigo 84, inciso II, e conceda indulto e comutação de penas, com audiência, se 
necessário, dos órgãos instituídos em lei. No Brasil, por tradição, anualmente, são editados decretos de indulto, conhecidos como decretos natalinos, por terem como base a data do Natal. É importante notar que não há obrigatoriedade constitucional ou legal de edição desses decretos. Porém, após 1988, eles foram editados em todos os anos, havendo situações em que mais de um decreto foi editado no ano (ALVES, 2016, p. 61). Certamente, é pouco provável que, à luz do Plano Nacional de Política Criminal e Penitenciária, tais decretos deixem de ser editados. Observa-se que, a cada ano, os decretos natalinos contemplam novas hipóteses de incidência, e os requisitos para a concessão do benefício são flexibilizados (ALVES, 2016, p. 61).

Essa tendência de ampliação, porém, não foi observada em alguns anos, quando houve endurecimento nas regras para a concessão do perdão. Com efeito, o primeiro Decreto Natalino do Século XXI, o de no 3.667, de 21 de novembro de 2000 (BRASIL, 2000), nitidamente, endureceu as regras para a concessão do benefício. Mas, ao que parece, essa mudança não partiu do CNPCP, pois, em 2000, vigorava a Resolução no 5, de 19 de julho de 1999, do CNPCP, de tendência afim aos Minimalismos, orientada pela intervenção mínima do Direito Penal. A análise de algumas atas de reuniões ordinárias do CNCPC, realizadas à época (265 e $268^{\mathrm{a}}$ reuniões), evidenciou que os decretos de indulto não seguiram a minuta entregue pelo órgão, a qual foi alterada tanto na assessoria do Ministério da Justiça quanto na da Presidência da República. E sugere que os cortes nas hipóteses de incidência e o endurecimento das regras de concessão do indulto teriam sido motivados pelo fato de um preso acometido de AIDS ter sido indultado no ano anterior, e cometido, logo em seguida, o assassinato de um jovem casal em Brasília/DF. Algumas notícias veiculadas pela mídia, naquele período, também sugerem a mudança no decreto de indulto, em razão do clamor popular decorrente do mencionado delito (ALVES, 2016, p. 123). Deve-se considerar, ainda, que o contexto no qual foi editado o decreto compreendia período de eleição nos municípios. Assim, as evidências sugerem que o endurecimento decorreu de decisão política, aparentemente influenciada pelo contexto social, marcado pela pressão popular e em período eleitoral.

Essa tendência restritiva seguiu-se no Decreto de 2001. Mas houve uma mudança substancial: a pena máxima para a concessão de indulto comum voltou a ser de seis anos. ${ }^{13}$ Maurício Kuehne, ex-Diretor-Geral do Departamento Penitenciário do Ministério da Justiça, de outubro de 2005 até julho de 2008, integrando o CNPCP de março de 2000 até maio de 2008, e que participou da Comissão de indulto dos Decretos de 2000 a 2005, na qualidade de relator das propostas, foi entrevistado em nossa pesquisa e apontou que a restrição às hipóteses de indulto visaram a alcançar situações daqueles que não estavam em privação de liberdade, como sursis, penas restritivas e livramento condicional, não havendo nenhuma orientação política, mas sim do próprio CNPCP, que passou a priorizar os efetivamente presos. De fato, na entrevista concedida, Maurício Kuehne expressou seu ponto de vista pessoal de que o indulto natalino deve ser endereçado para as pessoas que estão privadas de liberdade e não para outros casos, ressaltando "que a política de encarceramento não 
tem surtido efeito, não deu resultados positivos e, por isso, não deve ser acolhida." Disse, ainda, ser favorável à edição de decretos condicionais, ${ }^{14}$ pois "seria um contraponto à crítica de que o indulto estimula à impunidade, já que, nesse particular, o condenado manteria o compromisso de não voltar a delinquir naquele período até o aperfeiçoamento do benefício." (ALVES, 2016, p. 117-118).

No ano 2002, por outro lado, o decreto voltou a ter as hipóteses ampliadas. A ata da 285 ${ }^{\text {a }}$ Reunião Ordinária do CNPCP, ${ }^{15}$ realizada em 9 e 10 de dezembro de 2002, demonstra que as diretrizes da Resolução no 5 de 1999, que voltaram a ser seguidas, e a realização da primeira audiência pública sobre o decreto de indulto contribuíram para a ampliação das hipóteses de incidência do instituto. Apenas com hipótese de análise, é possível que o momento político - término de mandato do Presidente Fernando Henrique Cardoso, que não se candidatou a outro cargo político, também tenha sido relevante para essa ampliação, pois o "clamor popular", voltado à restrição do benefício, deixara de ser primordial para a edição do decreto natalino.

Por sua vez, o Decreto Natalino n ${ }^{\circ}$ 4.904, de $1^{\circ}$ de dezembro de 2003 (BRASIL, 2003), voltou a endurecer as regras na concessão do indulto. $O$ contexto, à época, ao que tudo indica, não favoreceu a manutenção da política expansionista do indulto, que se tentou retomar no ano de 2002. Esse momento encontra-se relatado pelo Ministro da Justiça, Márcio Thomas Bastos, presente à 286 Reunião Ordinária do CNCPC, ocorrida em 24 e 25 de março de 2003. Nessa reunião, o assunto recorrente foi o assassinato do Juiz Alexandre Martins de Castro Filho. A morte do Juiz Alexandre foi amplamente noticiada nos meios de comunicação, tendo ampla repercussão midiática. No mesmo mês, outro juiz foi assassinado em São Paulo, o juiz-corregedor Antônio José Machado Dias. Assim, o contexto de intensa divulgação na mídia da atuação do crime organizado no país, que culminara no homicídio de dois juízes de execução penal, sugere ter sido relevante para o endurecimento das regras concessivas do decreto de indulto, editado em 2003. O mais interessante é que, ainda no ano de 2003, no dia 17 de dezembro, o CNPCP editou a Resolução no 16, ${ }^{16}$ a qual dispôs "sobre as Diretrizes Básicas de Política Criminal quanto à prevenção do delito, administração da justiça criminal e execução das penas e das medidas de segurança”, que também se orientou por tendência criminal minimalista.

Portanto, vê-se que a presença de uma comunidade epistêmica de viés minimalista no âmbito do CNPCP contribuiu para que as hipóteses de incidência do indulto fossem bastante alargadas e os requisitos necessários à concessão do benefício relativizados. Para alguns, trata-se de injustificável afrouxamento na execução da pena (TRINDADE, 2013; STRECK, 2012), e, para outros, importante política criminal de humanização da pena e de desencarceramento, indispensável no sistema penitenciário brasileiro (VAY, 2014). No tocante ao requisito subjetivo, por exemplo, exigia-se anteriormente o exame criminológico à concessão de indulto para condenados por crimes cometidos com violência ou grave ameaça à pessoa. ${ }^{17}$ Em alguns anos, o indulto foi concedido de 
maneira condicional, só se aperfeiçoando após 24 meses da expedição do termo, se, nesse período, o beneficiário não praticasse falta grave. ${ }^{18}$ Atualmente, porém, a análise é realizada tão somente nos últimos doze meses anteriores à publicação do decreto, sendo que o requisito subjetivo só é afastado quando há a prática de falta grave, devidamente homologada pelo juiz da execução. ${ }^{19}$

A tendência ampliativa, contudo, não foi seguida em 2000, 2001 e 2003, quando foram impostas regras mais severas para a concessão do indulto, o qual teve, ainda, várias hipóteses de incidência retiradas dos textos dos decretos natalinos, nos respectivos anos. Por fim, o Decreto n ${ }^{o} 8.940$ de 22 de dezembro de 2016 (BRASIL, 2016b) voltou a assumir viés restritivo, endurecendo as regras para a concessão do indulto. Contudo, esse "endurecimento" partiu da decisão do então Ministro da Justiça, Alexandre de Moraes, encampada pelo Presidente da República, cujo decreto divergiu da linha sugerida pelo CNPCP, que mantinha a tendência ampliativa do instituto.

\section{A PRODUÇÃO DO DECRETO DE INDULTO DE 2014-2015: ASPECTOS POLÍTICO-CRIMINAIS E ATORES ENVOLVIDOS}

Conforme se viu anteriormente, entre os membros do CNCPC, são indicados 4 (quatro) representantes para compor a comissão responsável para apresentar Proposta de Decreto Presidencial de Indulto Natalino. No ano de 2014, essa comissão foi composta pelos Conselheiros Luis Geraldo Sant'ana Lanfredi (Presidente), Beatriz Vargas Gonçalves de Rezende (Relatora), Fabiana Costa Oliveira Barreto ${ }^{20}$ e Paulo Antônio Carvalho. ${ }^{21}$

Luis Geraldo Sant'ana Lanfredi possui graduação em Direito pela Universidade de São Paulo - USP, com especialização em Direito Penal e Criminologia (1995). Mestre em Direito Processual Penal pela Universidade de São Paulo - USP (2006). Mestre em Criminologia e Sociologia Jurídico Penal pela Universidade de Barcelona - UB - Espanha (2010). Doutorando em Direito Penal e Ciências Políticas pela Universidade de Barcelona - UB - Espanha (2012). Juiz de Direito em São Paulo. Vice-Presidente do Conselho Nacional de Política Criminal e Penitenciária (CNPCP). Coordenador dos Cursos de Pós-Graduação lato sensu em Direito Penal e Direito Processual Penal da Escola Superior de Advocacia da Seccional Paulista da OAB (ESA-OAB/SP). Professor Assistente da Escola Paulista de Magistratura (EPM). Professor Emérito da Escola Superior de Advocacia da OAB-SP (ESA-OAB/SP). ${ }^{22}$ Sua dissertação no programa de mestrado em criminologia e sociologia jurídico-penal, da Universidade de Barcelona, foi intitulada "El juez de garantías y el sistema penal - Replanteamientos sociocriminológicos críticos hacia la resignificación de los desafios del Poder Judicial frente a la política criminal brasileña."

Beatriz Vargas Gonçalves de Rezende possui graduação em Direito pela Universidade Federal de Minas Gerais (1985), mestrado em Direito pela Universidade Federal de Minas Gerais (1993) e doutorado em Direito pela Universidade de Brasília (2011). Atualmente é 
professora adjunta da Universidade de Brasília. Tem experiência na área de Criminologia e Direito, com ênfase em Direito Penal e Processo Penal. Membro da Comissão Anísio Teixeira de Memória e Verdade da Universidade de Brasília. Membro do Grupo Candango de Criminologia - GCCrim - da Faculdade de Direito da Universidade de Brasília (REZENDE, 2015). Sua tese no programa de Doutorado em Direito da Universidade de Brasília foi "A ilusão do proibicionismo: estudo sobre a criminalização secundária do tráfico de drogas no Distrito Federal". Atualmente, coordena projeto de pesquisa denominado "Descarcerização e sistema penal: a construção de políticas públicas de racionalização do poder punitivo".

Fabiana Costa de Oliveira Barreto possui mestrado em Direito pela Universidade de Brasília (2006). É promotora de justiça do Distrito Federal. Integra o Grupo Candango de Criminologia da Faculdade de Direito da Universidade de Brasília. Tem experiência na área de Direito, com ênfase em Direito Penal e criminologia e como principais linhas de pesquisa: alternativas penais e prisão provisória (BARRETO, 2015). Participa do projeto de pesquisa denominado "Descarcerização e sistema penal: a construção de políticas públicas de racionalização do poder punitivo."

Paulo Antônio de Carvalho é graduado em Direito pela UFMG e advogou em Belo Horizonte de 1971 a 1978, quando ingressou na magistratura. Foi juiz nas comarcas de Areado, Barão de Cocais e Caeté. Desde 1984, é juiz em Itaúna, sendo o titular da $1^{\text {a }}$ Vara Criminal do Júri e de Execuções Penais. Foi membro do Programa Novos Rumos na Execução Penal, do TJMG, destinado a fomentar a humanização das penas privativas de liberdade no Estado e a difusão da metodologia da Apac, no período de 2001 a 2010.23

Assim, a comissão encarregada de elaborar a minuta de decreto de indulto no ano de 2014 foi formada por dois juízes de direito, uma promotora de justiça e uma professora universitária, todos com ampla experiência na área criminal. A análise da produção técnica e dos projetos de pesquisa, extraída dos curriculum vitae, disponibilizados pela Plataforma Lattes, sugere que os integrantes da Comissão do indulto compartilhem, sob diferentes aspectos, parte dos ideários Minimalistas.

As entrevistas em profundidade permitem adensar o que identificamos a partir da análise de conteúdo (ALVES, 2016, p. 271-272). Beatriz Vargas, relatora da minuta do decreto de indulto no período da pesquisa, expôs sua percepção sobre o aumento das hipóteses de incidência de indulto:

A sensação é que o decreto tem sido pensado como instrumento de redução dos graves problemas do sistema penitenciária, cumprindo uma função humanitária; é regulador das deficiências do sistema penitenciário; não há problema de o indulto ser utilizado como instrumento de desencarceramento, desde que justificado por razões políticas dentro do sistema democrático; esse é o objetivo final do indulto. E o que justifica o aumento de hipóteses de indulto é o reconhecimento de que a piora do sistema penitenciário tem que receber resposta em vários níveis, inclusive no âmbito do indulto. Uma coisa é inversamente proporcional a outra: quanto mais o sistema penitenciário se deteriora, quanto mais se mostra violador de direitos humanos, mais hipóteses de indulto devem ser criadas. 
Muitas propostas foram encaminhadas à comissão por diversos setores sociais e professores que atuam na execução penal, e algumas foram incorporadas à minuta do decreto de indulto pelo CNPCP entregue ao Ministro da Justiça. Visando à elaboração do Decreto de 2014, no decorrer desse ano, diversas propostas de alteração do decreto anterior foram apresentadas. Apresentaram sugestões o Conselhos Penitenciários do Distrito Federal, do Rio de Janeiro e do Paraná, as Defensorias Públicas da Bahia, de Minas Gerais e do Maranhão, os Ministérios Públicos de Santa Catarina, de Minas Gerais, do Paraná e do Rio Grande do Sul, a Procuradoria da República no Estado de Goiás, a Psiquiatria Forense, a Secretaria de Justiça do Rio Grande do Sul, a Vara de Execuções Penais de Porto Alegre -RS, a Vara de Execuções Penais do Rio de Janeiro, a Fraternidade Brasileira de Assistência aos Condenados (FBAC), a Secretaria de Justiça do Paraná

Submetidas à discussão, o CNPCP apresentou ao Ministro da Justiça a minuta de decreto natalino ${ }^{24}$, cuja proposta final, voltada à ampliação do instituto, criava três novas hipóteses de indulto ${ }^{25}$ em relação àquelas existentes no Decreto de 2013 (Decreto n ${ }^{\circ}$ 8.172/2013) (BRASIL, 2013). Assim, o decreto concedia indulto às pessoas: condenadas que tenham filho ou filha com doença crônica (inciso VII); condenadas à pena privativa de liberdade que tenham sido mantidas em carceragens de unidades policiais, a despeito da existência de unidade prisional adequada na mesma comarca, por tempo superior à metade do total de sua pena (inciso XXII); e condenadas a pena privativa de liberdade em regime semiaberto, aberto ou aberto domiciliar que tenham suportado em situação de excesso ou desvio de execução (inciso XXIII).

Além disso, a minuta do CNPCP modificava algumas hipóteses reguladas no Decreto de 2013: 1) aumentava a pena-base para a concessão de indulto comum para dez anos (inciso I) ${ }^{26}$ 2) aumentava a pena prevista na hipótese de indulto especial descrita no inciso II para dez a quatorze anos; ${ }^{27}$ 3) aumentava a pena prevista na hipótese de indulto etário descrita no inciso III para dez anos; ${ }^{28} 4$ ) a situação de indulto assistencial a pessoas condenadas com filho ou filha passaria a ser dividida em quatro incisos ${ }^{29}$ (VI a IX): assim, o inciso VI regularia a benesse para casos de condenados com filho ou filha que necessite de cuidados especiais; o inciso VII, de filho ou filha com doença crônica grave; o inciso VIII, de filho ou filha com deficiência; e o inciso IX, de filho ou filha menor de dezoito anos. Assim, os incisos VII, VIII e IX deixariam de exigir a comprovação de que o filho ou filha necessitasse de cuidados especiais, exigência prevista apenas no inciso VI; 5) o indulto humanitário ${ }^{30}$ se tornaria possível aos condenados com mutilação de membro ou perda de função motora (alínea a do inciso XIV da minuta); 6) exigia para a concessão de indulto a pessoas submetidas à medida de segurança nos casos de substituição prevista no art. 183 da Lei de Execução Penal, ${ }^{31}$ que tenham suportado privação de liberdade, internação ou tratamento ambulatorial por tempo igual ao da condenação, excluindo o termo "cominada", contido na redação do Decreto de 2013. Além disso, previa que se fosse concedido o indulto em medida de segurança ao beneficiado que não tivesse recebido alta médica, este deveria ser encaminhado à rede de 
atenção à saúde do Sistema Único de Saúde - SUS (\$3 $3^{\circ}$ do artigo $1^{\circ}$ da minuta); 7$)$ admitia que a incapacidade econômica prevista nos incisos XIX e $\mathrm{XX}^{32}$ fosse demonstrada mediante declaração do condenado.

A proposta do CNPCP também contemplava disposição que reduzia pela metade as frações previstas como requisito temporal para a declaração de indulto, quando o condenado houvesse cumprido, de maneira ininterrupta, pelo menos $1 / 6$ do tempo total de sua pena em estabelecimento prisional em situação de superlotação, assim considerado o estabelecimento acima de sua capacidade ordinária $\left(\$ 5^{\circ}\right.$ do artigo $1^{\circ}$ da minuta). Este deveria ocorrer para os casos de comutação ( $\$ 3^{\circ}$ do artigo $2^{\circ}$ da proposta).

Incluía, ainda, um parágrafo único ao artigo $3^{\circ}$ para determinar que o condenado beneficiado por comutação, fundamentada nos decretos pretéritos, fizesse jus à nova comutação estabelecida em um sexto do tempo total de pena comutado pelos decretos anteriores. E propunha a inserção de um inciso no artigo $6^{\circ}$ para dispor que o indulto e a comutação de penas eram cabíveis ainda que o requisito temporal para sua concessão tenha sido cumprido antes da unificação decorrente da nova condenação por outro crime. Sugeria, ademais, nova redação para o $\$ 3^{\circ}$ do art. 11 , determinando ao juiz da execução que procedesse primeiro ao exame com base no decreto anterior. Além disso, previa a dispensa expressa do parecer do Conselho Penitenciário, conferindo nova redação ao $\S 5^{\circ}$ do art. 11 .

Porém, o Ministro da Justiça optou por manter as mesmas disposições do Decreto de 2013, o que foi acolhido pela Presidência da República, restando o Decreto no 8.380/2014 (BRASIL, 2014a) com o mesmo conteúdo do Decreto no 8.172/2013 (BRASIL, 2013). De fato, conforme já visto anteriormente, a edição dos decretos de indulto, como produção legislativa, constitui um processo programador decisório da política, inserido em um contexto complexo, que envolve diferentes variáveis, tais como os arranjos institucionais e políticos, as expectativas sobre eleitorado, o impacto das decisões na mídia, entre outros (MACHADO, 2012, p. 100). Cumpre destacar que o ano de 2014 envolveu eleições no país para Presidente da República, Governador de Estado, Senador, Deputado Federal, Estadual e Distrital. O primeiro turno ocorreu no dia 5 de outubro, e o segundo, no dia 26 de outubro de 2014. As eleições presidenciais foram marcadas por um grande equilíbrio, tendo a candidata Dilma Rousseff sido reeleita com $51,65 \%$ dos votos contra 48,35\% do candidato Aécio Neves. ${ }^{33}$ Noticiara-se nos meios de comunicação de massa sobre uma provável concessão de indulto a políticos condenados no "Escândalo do Mensalão."34

Assim, embora não tenha restringido a aplicação do indulto, endurecendo as regras para a sua concessão, a Presidente da República, em um contexto complexo, marcado por um período eleitoral em que as intenções de voto praticamente dividiam o eleitorado brasileiro, e por forte pressão midiática sobre uma provável concessão de indulto aos condenados no "Escândalo do Mensalão", editou, no ano de 2014, decreto de indulto diverso da minuta sugerida pelo CNPCP, repetindo integralmente as disposições do ano anterior. A sensação é de que novo aumento nas hipóteses de incidência do indulto e de maior flexibilização nos 
requisitos para a concessão do benefício poderia servir de munição para a oposição, implicando em dificuldades eleitorais para o governo.

\section{O DECRETO DE INDULTO DE 2016 - RESTRIÇÃO ÀS HIPÓTESES DE INCIDÊNCIA E A RENÚNCIA DE MEMBROS DO CNPCP}

O Decreto $\mathrm{n}^{\mathrm{o}}$ 8.940, de 22 de dezembro de 2016 (BRASIL, 2016b), restringiu as regras para a concessão do indulto. É relevante destacar, contudo, que esse endurecimento partiu da decisão do então Ministro da Justiça, Alexandre de Moraes, que optou por enviar ao Presidente da República minuta de decreto diversa da linha sugerida pelo CNPCP, que mantinha a tendência ampliativa do instituto.

A proposta de minuta aprovada pelo CNPCP, por maioria, seguiu o voto divergente apresentado pelo Conselheiro Gabriel de Carvalho Sampaio. Em síntese, a minuta mantinha as hipóteses de indulto coletivo contempladas no Decreto de 2015, e criava a comutação de pena, como medida de substituição da pena privativa de liberdade por restritiva de direitos. Contudo, o Ministro da Justiça não seguiu as sugestões do CNPCP e encaminhou ao Presidente da República outra proposta, culminando no Decreto n ${ }^{\circ}$ 8.940/2016 (BRASIL, 2016b), de teor restritivo. O único ponto não encampado pelo Presidente da República foi a vedação de indulto para crimes de peculato, concussão, corrupção ativa e passiva, prevaricação e advocacia administrativa, crimes contra o sistema financeiro e de "lavagem de dinheiro" contida na minuta enviada pelo Ministério da Justiça, mas não acolhida no Decreto $n^{\circ}$ 8.940/2016 (BRASIL, 2016b).

Assim, o Decreto de 2016 extinguiu várias hipóteses de incidência do indulto contempladas nos decretos anteriores, não acolheu o instituto da comutação de pena (como indulto parcial e mesmo como substituição de pena privativa de liberdade por restritiva de direitos), criou requisitos diferenciados para crimes cometidos com e sem violência ou grave ameaça à pessoa, eliminou o indulto da pena de multa e das penas restritivas de direitos e exigiu o cumprimento integral da pena de crimes impeditivos para a concessão de indulto de delitos não impeditivos. Na prática, o Decreto no 8.940/2016, mostrou-se de pouquíssima aplicação, representando um dos decretos mais restritivos após a Constituição da República de 1988.

Ao que consta, a divergência entre parte dos membros do CNPCP e as opções políticas do Executivo vieram a público no dia 25 de janeiro de 2017, quando sete membros do CNPCP, incluindo o seu Presidente, renunciaram ao mandato, expondo suas razões em carta renúncia, disponibilizada ao público, com fortes críticas à atuação do Ministro da Justiça. Assinaram a carta os Conselheiros, Alamiro Velludo Salvador Netto (Presidente), Gabriel De Carvalho Sampaio, Hugo Leonardo, Leonardo Costa Bandeira, Leonardo Isaac Yarochewsky, Marcellus De Albuquerque Uggiette e Renato Campos Pinto De Vitto. Do item 5 da carta, colhe-se o seguinte: 
Ressalta-se, nos últimos meses, o notório desprezo conferido ao Conselho nos temas mais relevantes ao Brasil na temática pertinente. Dias antes da crise prisional atingir patamar alarmante, a minuta de decreto de indulto aprovada pelo colegiado do CNPCP foi deixada integralmente de lado, optando-se pela formulação de um texto normativo que é, talvez, o mais restritivo em termos de liberdades já editado na história recente e republicana. Símbolo máximo disso é a exclusão do instituto da comutação. Conquistas gradativa e progressivamente obtidas foram abandonadas. A peculiar situação do encarceramento feminino, as dificuldades dos miseráveis presos brasileiros em arcarem com o pagamento das penas de multa, as enfermidades incuráveis do ambiente prisional e que afetam mortalmente centenas de condenados, a perpetuidade em que se transformam as medidas de segurança no Brasil, enfim. Tudo foi relegado ao esquecimento, a desprezar, inclusive, inúmeras pesquisas e trabalhos científicos a respeito da relevância da abordagem dessas peculiaridades no decreto de indulto (SALVADOR NETTO et al., 2017).

Assim, o Decreto de 2016 representou quebra na linha ampliativa do instituto do indulto, culminando com a saída de vários membros do CNPCP. Evidencia-se a divergência entre a decisão que materializou a política de indultos do governo Temer, aparentemente consubstanciada em ideário que remete à concepção de que as penas devem ser cumpridas conforme as sentenças prolatadas (justo merecimento), em detrimento do impacto gerencial/ atuarial que poderia justificar a adoção de uma política mais ampla de concessão dos indultos. De outro lado, não se pode inferir que a nova composição vá seguir o viés restritivo na aplicação do indulto, particularmente porque houve mudança no comando do Ministério da Justiça.

\section{CONCLUSÃO}

O presente artigo utilizou-se do conceito de comunidades epistêmicas (HAAS, 1992; ENGUÉLÉGUÉLÉ, 1998) com o objetivo de analisar a influência do Conselho Nacional de Política Criminal e Penitenciária (CNPCP) na produção dos decretos de indultos no Brasil, verificando se o CNPCP pode ser descrito como comunidade epistêmica que orienta a produção de indultos no Brasil e, caso positivo, se há nele uma visão teórica hegemônica/compartilhada.

O instituto do indulto, que, em última análise, extingue ou reduz a pena, ${ }^{35}$ ao longo dos anos, teve suas hipóteses de incidência ampliadas e os requisitos necessários à sua concessão flexibilizados. É fato que a tendência ampliativa não foi seguida em 2000, 2001 e 2003, quando foram impostas regras mais severas para a concessão do indulto, o qual teve, ainda, várias hipóteses de incidência retiradas dos textos dos decretos natalinos, nos respectivos anos, sendo que as evidências sugerem que o endurecimento havido nesses anos decorreu de uma decisão política, aparentemente influenciada pelo contexto social marcado pela pressão popular e em período eleitoral.

No tocante ao processo de elaboração dos decretos de indulto, identificamos que o CNPCP desempenha o papel de comunidade epistêmica no campo da política criminal e 
penitenciária no Brasil. Levando-se em conta que os paradigmas penais devem ser compreendidos como tipos ideais, marcados por hibridismos e posições nem sempre facilmente delimitadas, concluímos que a composição do órgão, nos últimos anos, compartilha posições próximas aos ideários minimalistas, o que se constitui em hipótese explicativa para incidência e a flexibilização das regras de concessão do benefício. Nossa percepção fundamentou-se, em especial, na análise do conteúdo dos Planos Nacionais de Política Criminal e Penitenciária, editados em 1999, 2003, 2011, 2015 e 2016 (vigente) e nas entrevistas em profundidade. É importante ressaltar que a produção do CNPCP não é indiferente à realidade carcerárias do país, e razões de ordem pragmática também foram relevantes na ampliação das hipóteses previstas nos decretos de indulto.

De outro ângulo, a produção dos decretos de indultos integra a esfera das decisões políticas. $\bigcirc$ que supõe considerar que a lógica gerencial se encontra presente na administração da superlotação carcerária e, particularmente, para lidar com carências estruturais do sistema penitenciário. De fato, a expertise teórica da comunidade epistêmica pode legitimar decisão política do Executivo, não raramente pressionada por fatores estruturais. As conjunturas políticas, como explicitamos no texto, podem alterar o cenário favorável à ampliação das hipóteses contempladas nos decretos de indulto. Assim, reforça-se a convicção de que a produção dos decretos de indultos se constitui em política em ação, instrumental ou simbólica.

\title{
EPISTEMIC COMMUNITIES AND THE PRODUCTION OF PARDON DECREES IN BRAZIL
}

\begin{abstract}
The article analyses the role of the National Council of Criminal and Penitentiary Policy (CNPCP) on the issuing of pardon decrees in Brazil, retrieving the concept of epistemic communities. In Brazil, the institution in charge of the edition of pardon decrees is the National Council for Criminal and Penitentiary Policy (CNPCP), which sends it, through the Minister of Justice, to the Presidency of the Republic for final consideration, production and publication of the decree. Thus, the research focused on two problems: to identify if the CNPCP may be described as an epistemic community that guides the production of pardon in Brazil, and, if so, if there is a hegemonic/shared theoretical vision. To answer such questions, the authors made use of content analysis, complemented with in-depth interviews with both current and former members of CNPCP. We concluded that the CNPCP is an epistemic community that guides the production of pardon in Brazil and that, over the past few years, its members share a minimalist theoretical hegemonic orientation, which is relevant to understand the increase of incidence and rule flexibility on the concession of the benefit. On another note, as the production
\end{abstract}


of decrees is a political matter, within the scope of the Presidency of the Republic, we identified social and political contexts in which the President of the Republic issued pardon decrees that differ from those proposed by the CNPCP, despite the technical knowledge of the community.

Keywords: Pardon. Epistemic Communities. CNPCP. Legislative Production. Brazil.

\section{COMUNIDADES EPISTÉMICAS Y LA PRODUCCIÓN DE LOS DECRETOS DE INDULTO EN BRASIL}

\section{RESUMEN}

El artículo analiza el papel del Consejo Nacional de Política Criminal y Penitenciaria (CNPCP) en la edición de los decretos de indulto en Brasil, retomando el concepto de comunidades epistémicas. En Brasil, el órgano encargado de elaborar la minuta del decreto de indulto es el Consejo Nacional de Política Criminal y Penitenciaria (CNPCP), que la remite, por medio del Ministerio de la Justicia, a la Presidencia de la Republica para apreciación y posterior publicación del decreto. Así, la investigación se articuló a partir de dos problemas: identificar si el CNPCP puede ser descrito como comunidad epistémica que orienta la producción de indultos en Brasil y, caso lo sea, se hay en ese órgano una visión teórica hegemónica/compartida. Para responder a esos problemas, se utilizó la técnica de análisis del contenido, complementada con entrevistas en profundidad de miembros y ex-miembros del CNPCP. Se concluyó que el CNPCP es una comunidad epistémica que orienta la producción de indulto en Brasil y que, en los últimos años, se nota que sus miembros comparten un ideario predominantemente minimalistas, lo que es una variante interesante para comprender el aumento de las hipótesis de incidencia y flexibilización de las reglas de concesión del beneficio. De otro ángulo, la producción de los decretos de indulto se inserte en el ámbito político, de competencia de la Presidencia de la Republica, lo que se percibe cuando, en contextos sociales y políticos específicos, el Presidente de la Republica, al definir el contenido de los decretos de indulto, editó decretos distintos de aquellos propuestos por el CNPCP, a pesar del conocimiento técnico de la comunidad integrante de ese órgano.

Palabras-clave: Indulto. Comunidad epistémica. CNPCP. Producción legislativa. Brasil.

1 O Brasil passou a ser o terceiro país com mais presos no mundo, de acordo com levantamento nacional de informações penitenciárias (Infopen) de 2015 e 2016, divulgado em 8 de dezembro de 2017. A população carcerária em 2015 foi de 698.618, e de 726.712 em 2016. Ver: https://oglobo.globo.com/brasil/brasil-o-terceiro-pais-com-mais-presos-no-mundo-diz-levantamento-22166270

2 A expansão penal é potencializada pela globalização econômica e pela integração supranacional, as quais passaram a exigir do Direito Penal demandas práticas na abordagem da criminalidade (SÁNCHEZ, 2001, p. 81-91). 
3 Artigo 63 da LEP.

4 As divergências entre os membros do CNPCP, segundo os entrevistados, não são consignadas, registrando-se apenas as propostas incorporadas à minuta que serão encaminhadas ao Ministro da Justiça.

5 Na qual são justificadas as alterações propostas.

6 Artigo 63 da LEP.

7 Na época, o órgão chamava-se Conselho Nacional de Política Penitenciária, tendo a atribuição de elaborar projetos, objetivando aperfeiçoar a execução penal e o regime penitenciário (artigo $3^{\circ}$, inciso VII, do Decreto $\left.\mathrm{n}^{\mathrm{o}} 76.387 / 1975\right)$. Posteriormente, ainda com a mesma denominação, sua atribuição foi aumentada, passando a elaborar diretrizes, estabelecer normas e coordenar a execução da política penitenciária no território nacional (redação alterada pelo Decreto no 84.632/1980).

8 Art. 64. Ao Conselho Nacional de Política Criminal e Penitenciária, no exercício de suas atividades, em âmbito federal ou estadual, incumbe: I - propor diretrizes da política criminal quanto à prevenção do delito, administração da Justiça Criminal e execução das penas e das medidas de segurança; II - contribuir na elaboração de planos nacionais de desenvolvimento, sugerindo as metas e prioridades da política criminal e penitenciária; III - promover a avaliação periódica do sistema criminal para a sua adequação às necessidades do País; IV - estimular e promover a pesquisa criminológica; V - elaborar programa nacional penitenciário de formação e aperfeiçoamento do servidor; VI - estabelecer regras sobre a arquitetura e construção de estabelecimentos penais e casas de albergados; VII - estabelecer os critérios para a elaboração da estatística criminal; VIII inspecionar e fiscalizar os estabelecimentos penais, bem assim informar-se, mediante relatórios do Conselho Penitenciário, requisições, visitas ou outros meios, acerca do desenvolvimento da execução penal nos Estados, Territórios e Distrito Federal, propondo às autoridades dela incumbida as medidas necessárias ao seu aprimoramento; IX - representar ao Juiz da execução ou à autoridade administrativa para instauração de sindicância ou procedimento administrativo, em caso de violação das normas referentes à execução penal; X - representar à autoridade competente para a interdição, no todo ou em parte, de estabelecimento penal.

9 Na época, o órgão chamava-se Conselho Nacional de Política Penitenciária, tendo a atribuição de elaborar projetos, objetivando aperfeiçoar a execução penal e o regime penitenciário (artigo $3^{\circ}$, inciso VII, do Decreto $\left.\mathrm{n}^{\mathrm{o}} 76.387 / 1975\right)$. Posteriormente, ainda com a mesma denominação, sua atribuição foi aumentada, passando a elaborar diretrizes, estabelecer normas e coordenar a execução da política penitenciária no território nacional (redação alterada pelo Decreto no 84.632/1980).

10 A ata foi disponibilizada no Diário Oficial da União, Seção 1, do dia 3 de setembro de 1980, p. 11.

11 O relatório final encontra-se disponível em Brasil (1976).

12 O teor da Resolução no 16/2003, do CNPCP, encontra-se disponível em: Brasil (2003).

13 Não foi identificado diploma normativo (lei, decreto, portaria etc.) que atribua expressamente ao CNPCP a função de apresentar minuta de decreto de indulto ao Ministro da Justiça.

$14 \mathrm{O}$ Decreto 3.667/2000 concedeu indulto ao condenado à pena privativa de liberdade não superior a 4 anos, que tivesse cumprido, até 25 de dezembro de 2000 , um terço da pena, se não reincidente, ou metade, se reincidente (art. $1^{\circ}$, inciso I). O Decreto 4.011/2001 (BRASIL, 2001) aumentou o limite da pena privativa de liberdade para 6 anos (art. $1^{\circ}$, inciso I).

15 São chamados de condicionais (ou condicionados), porque só se aperfeiçoa após o decurso de um prazo, dentro do qual deve o beneficiário cumprir algumas condições.

16 A Ata foi publicada no Diário Oficial da União, seção 1, do dia 22/04/2003, página 23.

17 Publicada no Diário Oficial da União, seção 1, do dia 22 de dezembro de 2003, páginas 34-35.

18 Essa exigência encontrava-se prevista no inciso II do $\$ 1^{\circ}$ do artigo $1^{\circ}$ do Decreto de 2003, tendo sido criada, pela primeira vez, em 1999 e repetida nos decretos seguintes. A partir de 2004, o exame criminológico não foi mais exigido para a concessão do perdão.

19 Os chamados indultos condicionais foram previstos nos decretos natalinos de 1996, 2000, 2001, 2003, 2004 e 2005. De 2006 até a presente data (2015), a Presidência da República não mais adotou os chamados indultos condicionais (ou condicionados). Na 324a Reunião Ordinária do CNCPC, realizada nos dias 25 e 26 de setembro de 2006 (ata publicada no Diário Oficial da União, seção 1, do dia 20 de novembro de 2006, páginas 17-18), optou-se pela não edição de decreto condicional, sob o fundamento de que o preso "não tem interesse pelo indulto, preferindo cumprir a pena a ter o indulto condicional, que resulta num acréscimo de mais dois anos vinculado ao sistema". $\mathrm{O}$ argumento apresentado não se mostra inequívoco, na medida em 
que o sentenciado continuaria vinculado ao sistema e, às vezes, até encarcerado, caso não fosse concedido o indulto. Mas, talvez, o maior óbice ao retorno do indulto condicional seja o da burocracia, que, ao que parece, traria prejuízos à celeridade processual necessária para a concessão do benefício. Isso porque exigir dos juízes da execução nova análise de aperfeiçoamento do indulto poderia implicar no atraso da declaração de novos perdões. Aliás, esse entrave burocrático foi relatado por vários membros do Conselho Penitenciário do Distrito Federal, o qual, nos anos de decretos de indulto condicional, era novamente ouvido sobre o aperfeiçoamento do perdão, implicando no atraso da análise da benesse. Ou seja, a gestão dos indultos condicionais é de difícil exequibilidade. Ressalte-se que há grande pressão por parte de setores da sociedade para que esses decretos condicionais voltem a ser editados.

20 Artigo $5^{\circ}$ do Decreto 8.615/2015 (BRASIL, 2015b).

21 Embora tenha sido publicado o nome de Fabiana Costa de Oliveira Barreto, o nome correto do membro do CNPCP é Fabiana Costa Oliveira Barreto.

22 Conforme Brasil (2014c).

23 Informações extraídas da Plataforma Lattes (LANFREDI, 2015).

24 Informações disponíveis em: < http://amagis.jusbrasil.com.br/noticias/100687992/juiz-paulo-antonio-de-carvalho-e-nomeado-para-o-cpcnp/>. Acesso em: 8 mar. 2015. Não foram encontradas informações na Plataforma Lattes.

25 Minuta cedida pela conselheira relatora, Beatriz Vargas.

26 Embora tenham sido incluídos cinco novos incisos, verifica-se que dois deles (incisos VII e VIII) resultaram do desmembramento do inciso VI do Decreto de 2013.

27 O Decreto de 2013 estabelecia pena entre não superior a oito anos.

28 O Decreto de 2013 estabelecia pena entre oito e não superior a doze anos.

29 O Decreto de 2013 estabelecia pena não superior a oito anos.

30 O Decreto de 2013 regulou a situação em apenas um inciso (VI), exigindo sempre que o filho ou a filha necessite de cuidados do condenado.

31 O Decreto de 2013 regulou o indulto humanitário no inciso XI.

32 Art. 183. Quando, no curso da execução da pena privativa de liberdade, sobrevier doença mental ou perturbação da saúde mental, o Juiz, de ofício, a requerimento do Ministério Público, da Defensoria Pública ou da autoridade administrativa, poderá determinar a substituição da pena por medida de segurança.

33 O Decreto de 2013 previu essas hipóteses nos incisos XVI e XVII.

34 Confira as informações em: Brasil (2014b).

$35 \mathrm{AP} \mathrm{n}^{\circ} 470 / \mathrm{DF}, \mathrm{STF}$.

36 Indulto total ou pleno e o indulto parcial, conhecido por comutação.

\section{REFERÊNCIAS}

ALVES, Reinaldo Rossano. Punir e perdoar: análise da política pública na edição dos decretos de indulto. Rio de Janeiro: Lumen Juris, 2016.

ANDRADE, Vera Regina Pereira. Pelas mãos da criminologia: o controle penal para além da (des) ilusão. Rio de Janeiro: Revan, 2012.

ANITUA, Gabriel Ignacio. Histórias dos pensamentos criminológicos. Tradução Sergio Lamarão. Rio de Janeiro: Revan, 2008.

AZEVEDO, Rodrigo; CIFALI, Ana Claudia Cifali. Seguridad pública, política criminal y penalidad en Brasil durante los Gobiernos Lula y Dilma (2003-2014). Cambios y Continuidades. In: SOZZO, Máximo (Org.). Postneoliberalismo y penalidad en América del Sur. Buenos Aires: Clacso, 2016. p. 29-95. 
BARRETO, Fabiana Costa de Oliveira. Currículo lattes. Disponível em: <http://buscatextual.cnpq.br/buscatextual/visualizacv.do?id=K4130444D0/>. Acesso em: 8 mar. 2015. BECKER, Howard S. Outsiders: estudos de sociologia do desvio. Rio de Janeiro: Zahar, 2008. BOURDIEU, Pierre. O poder simbólico. Bertrand, Rio de Janeiro, 1998.

BRASIL. Câmara dos Deputados. PRC 70/ 1976. Disponível em: <http://www.camara. gov.br/proposicoesWeb/prop_mostrarintegra? codteor $=1244772 \&$ filename $=$ Dossie + -PRC+70/1976>. Acesso em: 2 ago. 2015.

. Congresso Nacional. Câmara dos Deputados. Projeto de Lei 4.373, de 16 de fevereiro de 2016: cria a Lei de Responsabilidade Político-Criminal. Brasília: Câmara de Deputados, 2016a.

. Ministério da Justiça. Plano Nacional de Política Criminal e Penitenciária. 2011. Disponível em: <http://www.justica.gov.br/seus-direitos/politica-penal/cnpcp-1/anexos-cnpcp/plano-politica-criminal-e-penitenciaria-2011.pdf>. Acesso em: 2 mar. 2015.

. Ministério da Justiça. Plano Nacional de Política Criminal e Penitenciária. 2015a. Disponível em: < http:/www.justica.gov.br/seus-direitos/politica-penal/cnpcp-1/imagens-cnpcp/plano-nacional-de-politica-criminal-e-penitenciaria-2015.pdf>. Acesso em: 2 mar. 2015

. Senado Federal. Decreto no 3.667, de 21 de novembro de 2000. Concede indulto, comuta penas, e dá outras providências. Diário Oficial da União, Brasília, DF, 22 nov. 2000. Disponível em: <http://egis.senado.leg.br/legislacao/ListaPublicacoes.action?id=231046\& tipoDocumento $=$ DEC\& \&ipoTexto $=$ PUB $>$. Acesso em: 9 nov. 2014.

. Senado Federal. Decreto n ${ }^{\circ} 4.011$, de 13 de novembro de 2001. Concede indulto, comuta penas, e dá outras providências. Diário Oficial da União, Brasília, DF, 14 nov. 2001. Disponível em: <http://egis.senado.leg.br/legislacao/ListaPublicacoes.action?id=233852\& tipoDocumento $=$ DEC\& tipoTexto $=$ PUB $>$. Acesso em: 9 nov. 2014.

. Senado Federal. Decreto ${ }^{\circ}$ 4.904, de 1 de dezembro de 2003. Concede indulto condicional, comutação e dá outras providências. Diário Oficial da União, Brasília, DF, 2 dez. 2003. Disponível em: <http://legis.senado.leg.br/legislacao/ListaPublicacoes.action?id $=238001 \&$ tipoDocumento $=$ DEC \& tipoTexto $=$ PUB $>$. Acesso em: 9 nov. 2014.

. Senado Federal. Decreto no 8.172, de 24 de dezembro de 2013. Concede indulto natalino e comutação de penas, e dá outras providências. Diário Oficial da União, Brasília, DF, 24 dez. 2013. Disponível em: < http://legis.senado.leg.br/legislacao/ListaPublicacoes. action $? \mathrm{id}=267340 \&$ tipoDocumento $=$ DEC\&tipoTexto $=$ PUB $>$. Acesso em: 9 nov. 2014.

. Senado Federal. Decreto no 8.380, de 24 de dezembro de 2014. Concede indulto natalino e comutação de penas e dá outras providências. Diário Oficial da União, Brasília, DF, 24 dez. 2014a. Disponível em: <http://legis.senado.leg.br/legislacao/ListaPublicacoes. action? $\mathrm{id}=268469 \&$ tipoDocumento $=$ DEC\&tipoTexto $=\mathrm{PUB}>$. Acesso em: 9 nov. 2014 . 
. Senado Federal. Decreto no 8.615, de 23 de dezembro de 2015. Concede indulto natalino e comutação de penas e dá outras providências. Diário Oficial da União, Brasília, DF, 24 dez. 2015b. Disponível em: < http://legis.senado.leg.br/legislacao/PublicacaoSigen. action?id=414375\&tipoDocumento=DEC-n\&tipoTexto=PUB >. Acesso em: 4 out. 2017.

. Senado Federal. Decreto $\mathrm{n}^{\mathrm{o}}$ 8.940, de 22 de dezembro de 2016. Concede indulto natalino e comutação de penas, e dá outras providências. Diário Oficial da União, Brasília, DF, 23 dez. 2016b. Disponível em: <http://legis.senado.leg.br/legislacao/PublicacaoSigen.ac tion?id=414984\&tipoDocumento=DEC-n\&tipoTexto=PUB $>$. Acesso em: 4 out. 2017.

. Superior Tribunal de Justiça. Resolução $n^{\circ} 16 / 2003$. Disponível : <http://www.stj. jus.br/websti/Institucional/Biblioteca/Clipping/2Imprimir2.asp?seq_edicao $=484 \&$ seq_materia $=9352>$. Acesso em: 26 jul. 2015.

. Lei n ${ }^{\circ} 7.210$, de 11 de julho de 1984. Institui a Lei de Execução Penal (LEP). Diário Oficial da União, Brasília, DF, 13 jul. 1984. Disponível em: <http://www.planalto.gov.br/ ccivil_03/LEIS/L7210.htm >. Acesso em: 9 dez. 2014.

. Eleições 2014: resultados eleições 2014 para presidente. 2014b. Disponível em: <http://www.eleicoes2014.com.br/>. Acesso em: 4 ago. 2015.

. Conselho Nacional de Política Criminal e Penitenciária. Exposição de Motivos $\mathrm{n}^{\circ}$ 00201/2016 MJC, de 21 de dezembro de 2016: submete ao Presidente da República o Projeto de Decreto que concede indulto natalino [mensagem pessoal]. Mensagem recebida por: <reinaldorossano@yahoo.com.br>em 2 out. 2017.

. Conselho Nacional de Política Criminal e Penitenciária. Voto-Vista do Conselheiro Gabriel de Carvalho Sampaio, dezembro de 2016: Minuta de Decreto que concede indulto natalino. [mensagem pessoal].Mensagem recebida por: <reinaldorossano@yahoo.com.br > em 2 out. 2017.

. Portaria $\mathrm{n}^{\mathrm{o}} 1$, de 27 de maio de 2014, do Presidente do CNCPC. Diário Oficial da União, n. 102, maio 2014c. Disponível em: < http://pesquisa.in.gov.br/imprensa/jsp/visualiza/ index.jsp?.jornal $=1$ \&pagina $=121 \&$ data $=30 / 05 / 2014>$ > Acesso em: 19 out. 2017 .

CARVALHO, Salo de. Em defesa da lei de responsabilidade político-criminal. Boletim do IBCCrim, São Paulo, n. 193, p. 1-3, 2008.

COHEN, Ernesto; FRANCO, Rolando. Avaliação de projetos sociais. Petrópolis: Vozes, 1993.

DIETER, Maurício Stegemann. Política criminal atuarial: a criminologia do fim da história. 2012. 300 f. Tese (Doutorado em Direito) - Universidade Federal do Paraná, Paraná, 2012. Disponível em: <http://acervodigital.ufpr.br/bitstream/handle/1884/28416/R\%20-\%20T\%20-\%20MAURICIO\%20STEGEMANN\%20DIETER.pdf?sequence=1>. Acesso em: 18 nov. 2016.

D`URSO, Luiz Flávio Borges. Proposta de uma nova política criminal e penitenciária para o Brasil. Novos Estudos Jurídicos, Santa Catarina, v. 6, n. 11, p. 77-89, 2000.

ENGUÉLÉGUÉLÉ, Stéphane. As comunidades epistêmicas penais e a produção legislativa 
em matéria criminal. Tradução Wagner Amorim Madoz. Revisão Bruno Amaral Machado. Revista Droit et Societé, Paris, n. 40, p. 563-581, 1998.

FERRAJOLI, Luigi. Derecho y razón: teoría del garantismo penal. Tradução Pefecto Andrés Ibáñez et al. Madrid: Editorial Trotta, 2001.

FIGUEIREDO, Railander Quintão. Educação em serviços penais: diretrizes para a Escola de formação do sistema prisional em Minas Gerais. 2007. 181f. Dissertação (Mestrado em Edução) - Universidade Federal de Minas Gerais, Belo Horizonte, 2007. Disponível em: <http://www.bibliotecadigital.ufmg.br/dspace/bitstream/handle/1843/FAEC85JPED/ disserta_o_railander_quint_o_de_figueiredo.pdf?sequence=1>. Acesso em: 26 jul. 2015.

FRADE, Laura. O que o Congresso Nacional pensa sobre a criminalidade. 2007. 271 f. Tese (Doutorado em Sociologia) - Programa de Pós-graduação em Sociologia da UnB, Universidade de Brasília, Brasília, 2007.

GARLAND, David. The Culture of Control: crime and social contemporary society. Chicago: Chicago University Press, 2001.

. Beyond the Culture of Control. Critical Review of International Social and Political Philosophy, Vol. 7, n.2, 2004, pp. 160-189.

GAZOTO, Luís Wanderley. Justificativas do Congresso Nacional brasileiro ao rigor penal legislativo. 2010. 377 f. Tese (Doutorado em Sociologia) - Universidade de Brasília, Brasília, 2010.

GOFFMAN, Erving. Internados: ensaio sobre la situación de los enfermos mentales. Buenos Aires: Amorrortu, 1970.

HAAS, Peter M. Introduction: epistemic communities and international policy coordination. Internation Organisation, v. 49, n. 1, p. 1-35, 1992.

LUHMANN, Niklas. O direito da sociedade. México: Herder, 2005.

LANFREDI, Luís Geraldo Sant Ana. Currículo lattes. Disponível em: < http://buscatextual. cnpq.br/buscatextual/visualizacv.do?id=K4453304Z1>. Acesso em: 8 mar. 2015.

MACHADO, Bruno Amaral. Justiça criminal: diferenciação funcional, interações organizacionais e decisões. São Paulo: Marcial Pons, 2014.

. Discursos criminológicos sobre o crime e o direito penal: comunicação e diferenciação funcional. Revista de Estudos Criminais, Porto Alegre, v. 10, n. 45, p. 110-116, 2012.

; SLONIAK, Marcos. Disciplina ou ressocialização? racionalidades punitivas, trabalho prisional e políticas penitenciárias. Revista Direito GV, São Paulo, v. 11, p. 189-222, jan./jun. 2015.

; TAQUARY, Eneida Orbage de Britto. A tipificação do crime de desaparecimento forçado de pessoas: construção jusinternacional e a memória como categoria criminológica crítica. Revista de Estudos Criminais, Porto Alegre, v. 14, n. 63, p. 59-94, 2016. 
MARQUES, Fabiano Lepre. O Conselho Nacional de Política Criminal e Penitenciária e a proteção dos direitos humanos do recluso. Revista SJRJ, Rio de Janeiro, v. 20, n. 36, p. 39-62, 2013. Disponível em: <http://www4.jfrj.jus.br/seer/index.php/revista_sjrj/article/ viewFile/422/334>. Acesso em: 24 jul. 2015.

MATTHEWS, Roger. O mito do punitivismo revistado. In: MACHADO, Bruno Amaral. Justiça criminal e democracia II. São Paulo: Marcial Pons, 2015.

PIRES, A. Racionalidade penal moderna, o público e os direitos humanos na modernidade tardia. Novos Estudos do CEBRAP, São Paulo, v. 68, p. 39-60, 2003.

PRATT, John. Punishment and civilization. London: Sage, 2002.

RADBRUCH, Gustav. Filosofia do direito. Tradução Prof. L. Cabral de Mocada. Coimbra: Armênio Amado, 1997.

REZENDE, Beatriz Vargas Gonçalves de. Currículo lattes. Disponível em: <http://buscatextual.cnpq.br/buscatextual/visualizacv.do?id=K4767465H4/>. Acesso em: 8 mar. 2015.

SALVADOR NETTO, Alamiro Velludo et al. Carta de renúncia. 25 jan. 2017.Disponível em: <http://cdn01.justificando.cartacapital.com.br/wp-content/uploads/2017/01/26235023/ carta-renuncia-conselho-nacional-MJ1.pdf>. Acesso em: 2 out. 2017.

SÁNCHEZ, Jesus Maria Silva. La expansion del derecho penal: aspectos de la política criminal em las sociedades postindustriales. Madri: Edisofer S.L, 2001.

STRECK, Lenio Luiz. Senso incomum: direitos do cidadão do tipo "azar o seu". 2012. Disponível em: <http://www.conjur.com.br/2012-set-13/senso-incomum-direitos-cidadao-tipo-azar>. Acesso em: 11. mar. 2015.

TRINDADE, André Karam. Indulto é resquício absolutista ou garantia democrática? 2013. Disponível em: <http://www.conjur.com.br/2013-jan-05/diario-classe-indulto-resquicio-absolutista-ou-garantia-democratica >. Acesso em: 2 mar. 2015.

VAY, Giancarlo Silkunas. O indulto natalino e os fantasmas que queremos apaziguar. 2014. Disponível em: <http://blogs.odiario.com/padredivanpedro/2014/12/30/indulto-de-natal/>. Acesso em: 11.mar. 2015.

ZACKSESKI, Cristina; MACHADO, Bruno Amaral; AZEVEDO, Gabriela. Dimensões do encarceramento e desafios da política penitenciária no Brasil. Revista Brasileira de Ciências Criminais, São Paulo, v. 126, n. 24, p. 291-331, dez. 2016.

Submetido: 7 jun. 2017

Aprovado: 6 out. 2017 